\title{
NEW ANTAGONISMS IN ECUADORIAN POLITICS ${ }^{1}$
}

\begin{abstract}
The article considers certain results of the left political project "Citizens' Revolution" developed in Ecuador at the beginning of the XXI century. It argues that in the framework of socially oriented reformism and strengthening of state institutions, an increase in political controversy and a surge in public discontent revealed the presence of multidirectional contradictions. Among them ideological confrontation, conflict between the government and society, internal party differences and clash of identities are reviewed.
\end{abstract}

Key words: Ecuador, political reforms, divided society, socio-political polarization, indigenous peoples, protest movements.

DOI: 10.51180/RPS.2020.15.2.008.

\section{Author}

\section{Vorotnikova Tatiana}

Academic secretary Institute for Latin America of Russian Academy of Sciences, PhD of Political science

(Moscow, Russia)

\section{Introduction}

ก The efficiency of state policy can be measured by a number of methods. The analysis of public opinion is the one that quite clearly indicates if the government is doing right or wrong. The national survey conducted in Ecuador in 2015 (Opinión Pública Ecuador) showed that the implementation of the Rafael Correa's political project called the "Citizens' revolution" contributed to substantial positive changes. Ecuadorians approvingly qualified infrastructure development and reforms in the social security system [2]. The expansion of access to education, opening of new schools and universities, as well as improvement in basic health services, free access to medicine, renovation of hospitals, and investment in medical centers and equipment, could be mentioned among the most important governmental achievements [18].
According to the monitoring of the well-known public opinion survey in Latin America, Latinobarometro, the attitude of Ecuadorians to democracy strengthened between 2005 and 2017 (a year before the government of the President Rafael Correa came to power and the time when he left the presidential post). If in 2005 , only $14 \%$ of respondents were satisfied with the level of democracy in their country, then, in 2017 more than half of them (51\%) responded affirmatively [9]. In comparison to the widespread disillusionment with the functioning of democratic institutions, these figures speak for themselves.

The transition from the military regime that had collapsed in 1978 to modern Ecuadorian democracy was not easy. For about 30 years, the new political system suffered from an extremely high level of atomization, ideological polarization, and

\footnotetext{
1 The research was funded by RFBR, project № 18-014-00042 «Political polarization and mechanisms of consolidation of divided societies in Latin America. Opportunities and limits of comparative experience for Russia».
} 
incapacity of numerous parties and political movements to cooperate [6]. Obviously, the appearance of a coalition party PAIS Alliance (Movimiento Alianza PAIS Patria Altiva i Soberana) on the divided Ecuadorian political space attracted broad civil support. Its precise ideological platform and consolidated political position provided sizeable "credit of confidence" and were favorably considered by people.

\section{Internal split}

For a deeper understanding of the process of "Citizens' revolution", it is worth referring to the political climate in which the party has been founded and raised. After recovery to the democratic track, the Ecuadorian party system suffered from weak institutions and extreme multiparty structure. The main leading parties came back to the political space but the new Ecuadorian democracy faced the problem of political fragmentation and electoral volatility [10]. For a long time, the Ecuadorian system continued to be one of the most unstable in Latin America.

However, at the beginning of the XXI century, the situation began to change. The crisis of legitimacy of the new democratic institutions, especially political parties, was one of the most important issues in Ecuador of that period, which led to the decline of their electoral support. In 2000-2002, almost $60 \%$ of Ecuadorians believed that "democracy can function without political parties" [9]. Thus, in the elections of 2006, the traditionally dominated parties gained only $22 \%$ of the seats in the National Assembly [16].

This trend marked the beginning of a deep transformation in the Ecuadorian political ambit. The same year Rafael Correa, who did not belong to the prevailing political elite, triumphed in the presidential campaign. By integrating almost 30 political parties and left-wing movements into a broad coalition, his PAIS Alliance attained the highest percentage of representation for 25 years of modern Ecuadorian democracy and received an absolute parliamentary majority [12]. In the next 3 elections, the party endorsed its success. The results of the Presidential election also demonstrated the viability of the ruling left bloc. Though R. Correa made a decision not to run for another term (that provoked a number of speculations regarding his further participation in politics), his Vice President Lenin Moreno won in the second round with the support of $51.16 \%$ [15].

Destabilization of the political situation began unexpectedly and was related to the conflict between former associates, Rafael Correa and the new head of the Cabinet, Lenin Moreno. It was instigated by anticorruption investigations initiated immediately after the 2017 elections affecting the country's top officials, including Vice President Jorge Glas. Mutual accusations of "betrayal" of the ideals of the "Citizens' revolution" turned into a large-scale confrontation between supporters of the ex- and new President on a number of issues concerning the vector of development, economic measures, style of leadership, etc. With the split between Correístas and Morenistas the hegemony of PAIS Alliance was over [20], a fact that the results of local elections in March 2019 clearly confirmed [11].

One of the first signs of political and ideological discontinuity referred to the abolishment of the Constitutional norm introduced in 2015, concerning president re-election for an unlimited number of times. In a national referendum held in February 2018, the majority of Ecuadorians supported the return of the restriction that allowed only two four-year presidential mandates as it was already fixed in the Main Law of 2008 [3]. The second step revealed itself in the sphere of economics. In the context of struggling to reduce its fiscal deficit and unfavorable external conditions, the new administration shifted its left-oriented policy towards neoliberal recipes included the acceptance of the IMF lending program and the announcements for the privatization of stateowned enterprises [11]. 
Chances to maintain the same political vector that had received popular support and strong presidential leadership melted away. Ecuadorian politics has returned to the pre-Correa times with its parliamentary fragmentation and fragile coalitions [20]. The foundation on which R. Correa's "Citizens' revolution" had been built, turned out to be not that strong. However, why and how could it happen?

\section{Ideological confrontation}

For Latin American society, two paradigms of development have been and continue to be of great importance. Until now, the confrontation between socially oriented and neoliberal models is a noticeable factor that affects polarization of the celectorate and brings constant heated debate.

Throughout the "Citizens' revolution", PAIS Alliance, which merged Ecuadorian left and left-center, was facing stiff opposition. Being mainly relied on large exportoriented business and political class that in neoliberal times had benefited from privileged access to public resources and management, elites did not agree with the socialist ideas of R. Correa and his style of leadership. Private capital was discontent with the transition of oil and gas production sector and agro-industrial complex to the state control and tried to counter governmental plan for fiscal reform and tax evasion measures by magnifying pressure on private mass-media which at the beginning of the Correa's presidency controlled almost all media space in the country [4].

However, during a few following years, traditional business and media actors began to lose their positions. The creation of a powerful state sector, including TV channels and radio (TC Televisión, Gama TV, Ecuador TV, Radio Universal, etc.), newspapers (El Telégrafo), magazines (La Onda, El Agro), news agencies (Agencia Pública de Noticias del Ecuador y Suramérica), as well as the adoption of the Ecuadorian Communication Law (2013) limited finan- cial and juridical competence of private media companies [4]. Nevertheless, the replacement of bureaucracy by the new generation of political technocrats, who consolidated their power by state agreements and contracts with international capital, did not mean the complete exclusion of the former elite from the political class.

The strength of the Ecuadorian opposition relied on the clear and solidary approach towards the return to the neoliberal model of development. At the last elections in 2017 a candidate with the right-wing program, Guillermo Lasso, one of the country's leading bankers, successfully competed with Lenin Moreno, who promised to continue social reforms. In comparison to Rafael Correa's triumph in 2009 and 2013, Moreno's electoral support turned out to be not so solid. In the first round, he failed to get the necessary $40 \%$ of votes, as well as in the second round the vote was a tie nearly equally [5]. In addition to the media sector case, serious economic struggling, caused by external shocks and low prices on commodities, reverberated on abatement of the regime's vote-bank and pushed the rating for opposition parties. It demonstrated that despite notable achievements made by the government during the years of the "Citizens' revolution", in the last few years political polarization and social discontent have grown considerably [19].

\section{Identity clash}

Another factor of polarization is the clash of civilizational paradigms in the multi-ethnic and multicultural society. Perhaps, the strongest movement of indigenous peoples in Latin America developed in Ecuador and its presence on the national and regional political arena is becoming increasingly influential.

In the previous neoliberal period, while traditional peasant institutions were being severely weakened, the indigenous community managed to assume a part of political opposition and succeed in design- 
ing anti-neoliberal agenda primarily based on the rights for identity. Confederation of Indigenous Nationalities of Ecuador (Confederación de Nacionalidades Indígenas del Ecuador, CONAIE) reached national level in 1990 by organizing its first popular uprising and henceforth kept arranging several large-scale protests. In the electoral field, the Pachakutik party (Movimiento de Unidad Plurinacional Pachakutik-Nuevo País) assembled indigenous discourse by developing a broader left ideological platform. The party had powerful influence at the local level and successfully competed with the PAIS Alliance for the presence in the Parliament.

Further antagonism between the state and the indigenous peoples was grounded on a contradiction that was inherent to the practice ofp R. Correa's decisions. According to them, formal commitment to the principles of participatory democracy, protection of native values and traditions were not really followed by the governmental policy, intended to strengthen executive power and promote extractivist development model [14]. At the beginning of the process, the vast majority of indigenous and environmental organizations supported the draft of the new Constitution that recognized the rights of nature and indigenous peoples, and placed special emphasis on multiculturalism, pluralism, and participation [17]. However, these reforms conducted to the marginalization of the indigenous movement by weakening their mobilization capacity, pushing towards alliance policy with other social sectors, and institutional participation [8]. Despite attractive declarations and budding initial conditions for fruitful cooperation between Correa's left-wing political project and the indigenous movement, relations between them quickly soured, especially with CONAIE.

The main reason for that was the expansion of export-oriented economic policies, related to extractive industries and support for agro-industrial elites who challenged the state's constitutional commitments. Since the very beginning of his presidency, R. Correa considered the resistance of indigenous peoples and environmentalists as an obstacle to "progressive extractivism" [8]. State policy aimed to increase exports by intensifying the extraction of minerals, hydrocarbons, and agricultural crops, which would have helped the government to accumulate capital for subsequent reinvestment in infrastructure and social security. Though Lenin Moreno expressed a relatively friendlier approach to indigenous peoples, the constructive and fruitful dialogue of the state towards the indigenous movement was not established [13].

Though indigenous peoples are a minority, their political voice has consolidated, as they were able to expand their agenda by offering concrete political solutions to long-standing national problems. This strategy attracted broader segments of the population making their slogan "Not only for indigenous peoples" (Nada solo para los indios) work [8].

\section{Government and civil society disagreement}

Civil society as a counterforce to Correa's political project first emerged during the crisis in September 2010, known in Ecuador as the 30-S. Police officers across the country revolted amid anger at a new law cutting benefits for public servants. President Rafael Correa was held hostage for several hours while military forces seized airports and the National Assembly building [1]. Among those who might have supported the revolt were bankers who were dissatisfied with the new financial rules and taxes, together with the members of the right-wing opposition. [2] Nevertheless, the details of those events until now are quite controversial and sometimes are considered as a coup attempt.

The second signal for the government came in spring 2015 from privately- owned media and opposition parties that managed to mobilize people against inheritance tax law. The reform was aimed to 
affect mainly 2 percent of the rich class, but it resulted in large-scale anti-governmental demonstrations. Right-wing politicians such as Jaime Nebot, the Mayor of Guayaquil, the economic center of the country, who advocated "regional autonomism" [7], and private media companies played an important role in this mobilization, as well as indigenous organizations and other social groups who joined the protest. Correa's administration seemed not to be prepared to face the crisis. It had to repeal the law and agreed to open consultations with various sectors of the Ecuadorian society.

The third and most striking wave of protests happened in autumn 2019 when indigenous peoples' and labor unions cooperated to upraise civil society against neoliberal economic package approved by IMF. Triggered by controversial measure to eliminate fuel subsidies (valid since the 1970s), which could have a strong negative impact on the most vulnerable social strata, the crisis went so far that Moreno's cabinet had to declare the state of emergency. Just after difficult negotiations, the authorities could convince protesters to accept the requirement to stop the strikes in return for the abolition of austerity.

Protest movement and, in particular, the impulsive reaction of the officials demonstrated the fragility of the "Citi- zens' Revolution" in conditions of confrontation with various groups of interests that opposed certain state reforms and corresponding decisions taken by the government.

\section{Conclusions}

The model proposed by the left government in Ecuador assumed social and political consolidation based on the strengthening of state institutions and socially oriented reformism. However, challenged by a number of internal and external socio-economic factors, the government policy led to an increase in political controversy and surge in public discontent. Protests followed that revealed the presence of multidirectional conflicts, such as deterioration of the well-being of citizens, growth of social inequality, as well as disappointment in the results and degree of implementation of the promised reforms. Some of them, such as contradictions between indigenous peoples and the state, have deep historical roots. The question of choice of an adequate political model continuously swings Ecuadorian society. In addition to the presence of some constant factors, the internal antagonism in the Ecuadorian left movement has established a precedent that can lead to a new political configuration.

\section{References}

1. Becker M. The Correa coup // Latin American Perspectives. - 2015. — Vol. 43, issue 1. — P. 71-92.

2. Clark P., García J. Left Populism, State Building, Class Compromise, and Social Conflict in Ecuador's Citizens' Revolution // Latin American Prespectives. — 2018. — Vol. 46, issue 1. P. 230-246.

3. CNE proclama los resultados definitivos del referéndum y consulta popular del 2018 en Ecuador //El Universo. —URL: https://www.eluniverso.com/noticias/2018/02/08/nota/6615580/ vivo-audiencia-publica-escrutinio-referendum-consulta-popular; https://www.eluniverso. com/noticias/2018/02/08/nota/6615580/vivo-audiencia-publica-escrutinio-referendumconsulta-popular 